Article

\title{
Influence of the Morphology of Core-Shell Supports on the Immobilization of Lipase B from Candida antarctica
}

\author{
Martina C. C. Pinto ${ }^{1}$, Denise M. G. Freire ${ }^{2}$ and José Carlos Pinto ${ }^{1, *}$ \\ 1 Programa de Engenharia Química, COPPE, Universidade Federal do Rio de Janeiro, Rio de Janeiro, \\ Caixa 68502, Brazil; E-Mail: mpinto@peq.coppe.ufrj.br \\ 2 Departamento de Bioquímica, Instituto de Química, Universidade Federal do Rio de Janeiro, \\ Rio de Janeiro, Caixa 68502, Brazil; E-Mail: freire@iq.ufrj.br \\ * Author to whom correspondence should be addressed; E-Mail: pinto@peq.coppe.ufrj.br; \\ Tel.: +55-21-3938-8779; Fax: +55-21-3938-8300.
}

Received: 19 May 2014; in revised form: 28 July 2014 / Accepted: 1 August 2014 /

Published: 18 August 2014

\begin{abstract}
Core-shell polymer particles with different properties were produced through combined suspension-emulsion polymerizations and employed as supports for immobilization of lipase B from Candida antarctica. In order to evaluate how the morphology of the particles affects the immobilization parameters, empirical models were developed to describe the performance of the biocatalysts as a function of the specific area, volume of pores and average pore diameter of the supports. It was observed that the average pore sizes did not affect the enzymatic activities in the analyzed range of pore sizes. It was also observed that the increase of the specific area (and of the volume of pores) led to higher enzyme loadings, also leading to an increase in the esterification activity, as expected. However, when the specific area (and volume of pores) increased, the hydrolytic activity and the retention of hydrolytic activity of the biocatalysts decreased, indicating the existence of diffusional limitations for some hydrolytic reactions, probably because of the high reaction rates.
\end{abstract}

Keywords: core-shell particles; polystyrene; immobilization; lipase B from Candida antarctica 


\section{Introduction}

Among enzymes, lipases have received considerable attention both in the scientific literature and in the commercial market [1]. Lipases represent about 5\% of the world enzyme market and, because of their wide-ranging applications, this market is expected to grow in the coming years [2]. Lipases can catalyze different reactions, including hydrolysis, esterification and transesterification reactions, with high selectivity and specificity [2-5]. For this reason, lipases find widespread use in many different areas, including applications in the food, pharmaceutical, cosmetics and biosensors fields [1,6]. Lipases can also be employed for the treatment of effluents [7,8] and the production of biodiesel [9-11].

Nevertheless, soluble enzymes cannot be recovered easily at the end of the reaction process, which limits the development of continuous operations and increases the operation costs, as enzymes with the desired degree of purity are usually very expensive. In order to minimize these problems, it is normally recommended that enzymes be employed in the immobilized form [12], facilitating the recovery of the biocatalysts at the end of the process, enabling the conduction of continuous process operations and allowing for enzyme reuse [12-15]. Additionally, some enzymatic properties can also be enhanced by the immobilization process, such as activity, selectivity, specificity and stability $[12,14,15]$. Improvement of enzyme performance can be related to modification of the enzyme structure (due to chemical and physical interaction with the support), generation of a more favorable reaction environment in the surroundings of the enzymes (due to interaction of the support with the reactants and solvents), existence of diffusional limitations (modifying concentration gradients along the pores), among others [16-21].

Enzyme immobilization can be performed through chemical reactions or chemical and physical interactions between the enzymes and the supports $[11,12,15]$. However, it is important to note that, depending on the particular method employed for enzyme immobilization, the produced biocatalyst may present different properties. The most common method employed for lipase immobilization is the adsorption of the enzyme on the surface of a solid support $[2,5,11]$.

It is interesting to observe that most lipases present a lid that covers the active center of the enzyme molecule. However, in contact with hydrophobic surfaces these enzymes show an open form, exposing the hydrophobic pocket of the enzyme and enhancing the enzymatic activity [5]. One of the most used lipases is lipase B from Candida antarctica (CAL-B) [2,22,23]. Although the structure of this enzyme presents a very small lid, that does not completely block its active center [2,24], it is able to absorb onto hydrophobic carriers $[2,25]$. The main properties of CAL-B have been discussed by many authors and can be found elsewhere [2,22-25]. However, it is important to notice that CAL-B is a globular protein constituted by 317 aminoacids and presenting a molecular weight of $33 \mathrm{kDa}$ and isoelectric point of 6.0.

There are many supports used for lipase immobilization, including natural polymers, such as chitin, chitosan, gelatin, dextran and cellulose, and synthetic polymers, such as polyacrylamide, poly(vinyl alcohol), polystyrene, and others [26,27]. As the properties of the support can affect the activity of the biocatalyst, many studies are being conducted to allow for development of new synthetic polymer supports, since most polymers can be synthesized easily and at low cost.

In this context, core-shell polymer particles produced through combined suspension/emulsion polymerizations can be potentially employed as supports for cell and enzyme immobilizations [28]. These supports can exhibit very porous morphology and adsorb high amounts of proteins [2,28-30]. Moreover, the combined suspension/emulsion polymerization process enables the easy modification of 
the chemical and physical properties of the support surfaces, allowing for adjustment of the support properties in order to improve the interaction of the particularly analyzed enzyme with the support, leading to tailor-made supports for specific enzymes [2,29]. Furthermore, particles can be synthesized in a single process step, not requiring necessarily the implementation of additional process steps for functionalization of the final polymer particles [29].

Figueiredo et al., employed porous polystyrene core-shell particles produced through combined suspension/emulsion polymerization for the adsorption of lysozyme, aiming at separating this protein from the protein medium [30]. It was observed that large amounts of protein could be recovered with the help of the core-shell particles with low costs. More recently, Cunha et al., employed similar core-shell polymer particles for immobilization of commercial lipase B from Candida antarctica (CAL-B), obtaining performances for esterification and hydrolysis that were better than reported for other commercial supports [2].

More recently, Besteti et al., prepared different enzymatic CAL-B catalysts and observed that more active biocatalysts (based on hydrolytic activity) could be obtained with core-shell polymer supports containing polystyrene in the core and poly (methyl methacrylate) in the shell [31]. According to the authors, the presence of polar monomers in the shell can improve the efficiency and yield of immobilization and retention of activity of the immobilized CAL-B, as a consequence of the less intense interaction established between the enzyme and the support, which prevents distortions of the tertiary structure of the enzyme. Despite that fact, Besteti et al. did not analyze the effect of polymerization conditions and final polymer support morphology on the performance of the final biocatalysts [31]. For this reason, it becomes necessary to produce supports with different morphological properties (with distinct specific areas, pore diameters and volume of pores) and to evaluate how the support characteristics affect the immobilization parameters. This can allow for optimization of CAL-B performance in many applications, such as those related to the kinetic resolution of myo-inositol derivatives [32-36].

Based on the previous paragraphs, the main objective of the present work was to characterize how the morphology of core-shell polystyrene particles produced through combined suspension/emulsion polymerizations (specific area, volume of pores and average pore diameter) affects the immobilization parameters of CAL-B (such as immobilization yield and retention of enzymatic activity in hydrolytic and esterification reactions). In order to do that, core-shell particles with different properties were initially prepared through manipulation of some operation parameters of the combined suspension/emulsion polymerization process. Afterwards, the immobilization of CAL-B on the previously prepared particles was performed through physical adsorption. Finally, the immobilization parameters were analyzed quantitatively with help of empirical models and standard statistical analysis. Polystyrene was used because this polymer presents high hydrophobicity and good mechanical strength, while CAL-B is one of the most used lipases [2,22,23]. 


\section{Results and Discussion}

\subsection{CAL-B Immobilization}

Figure 1 illustrates the enzyme immobilization kinetics, based on the hydrolytic activity, for different supports. It is possible to observe that most supports are able to absorb more than $80 \%$ of the enzyme activity of the initial solution under the analyzed immobilization conditions. It is particularly important to mention that the supports that adsorbed the smallest amounts of enzyme also presented the lowest specific areas. It is also important to observe that, although the core particles exhibited very low specific areas, significant amounts of enzyme were absorbed by core particles, probably because of the interaction forces that exist between the lipases and the hydrophobic surfaces of the supports [5]. Figure 2 shows the evolution of protein concentrations in the aqueous solution during the enzyme immobilization experiments, confirming the results of Figure 1 and showing that most supports could absorb more than $60 \%$ of the initial amount of protein. This supports the idea that the observed decrease of hydrolytic activity was caused by the increase of the amount of protein adsorbed onto the supports surfaces during the immobilization process.

Figure 1. Kinetics of the enzyme immobilization based on the hydrolytic activity: (a) first group of supports and (b) second group of supports.

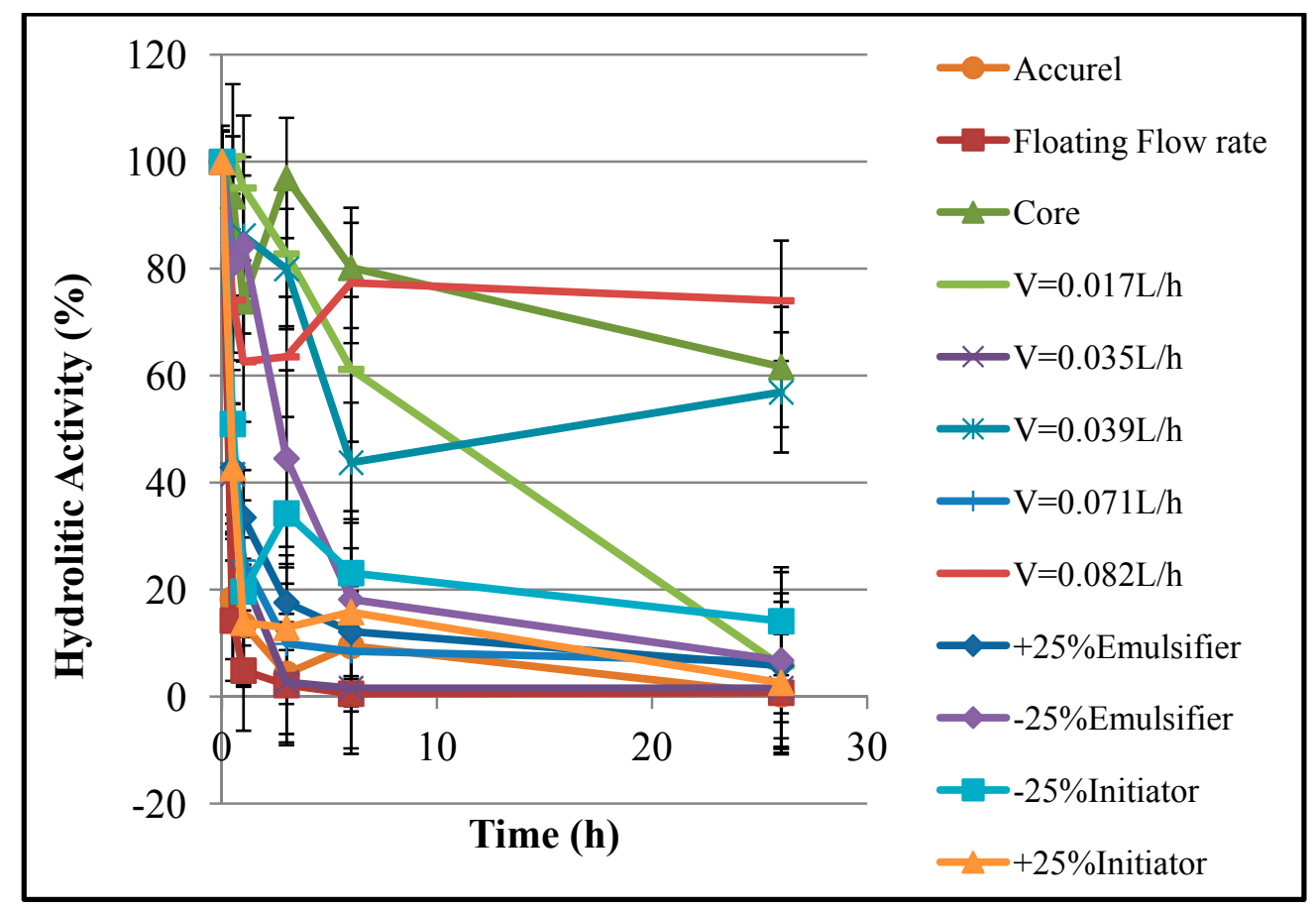

(a) 
Figure 1. Cont.

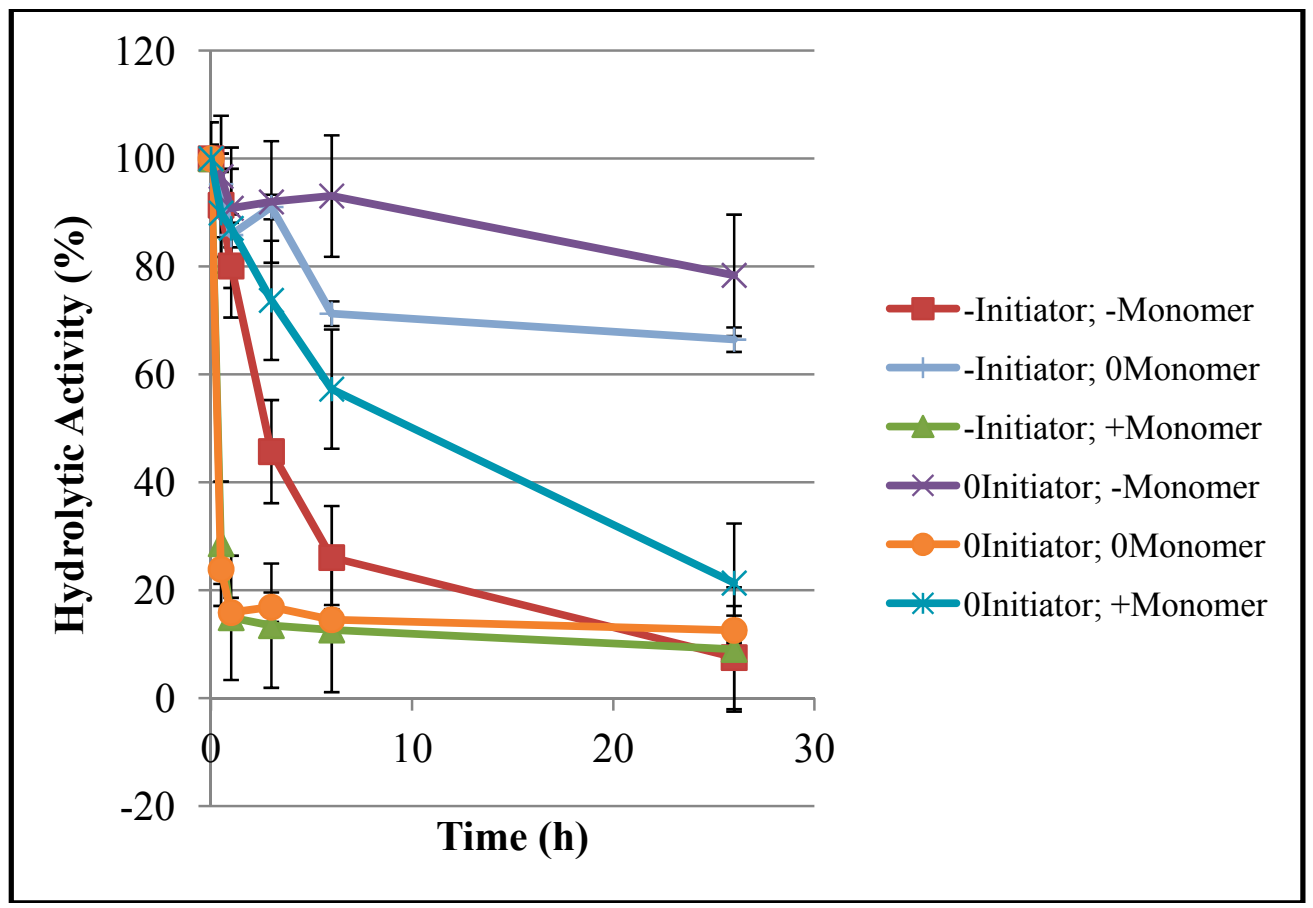

(b)

Figure 2. Kinetics of the enzyme immobilization based on the protein concentration: (a) first group of supports and (b) second group of supports.

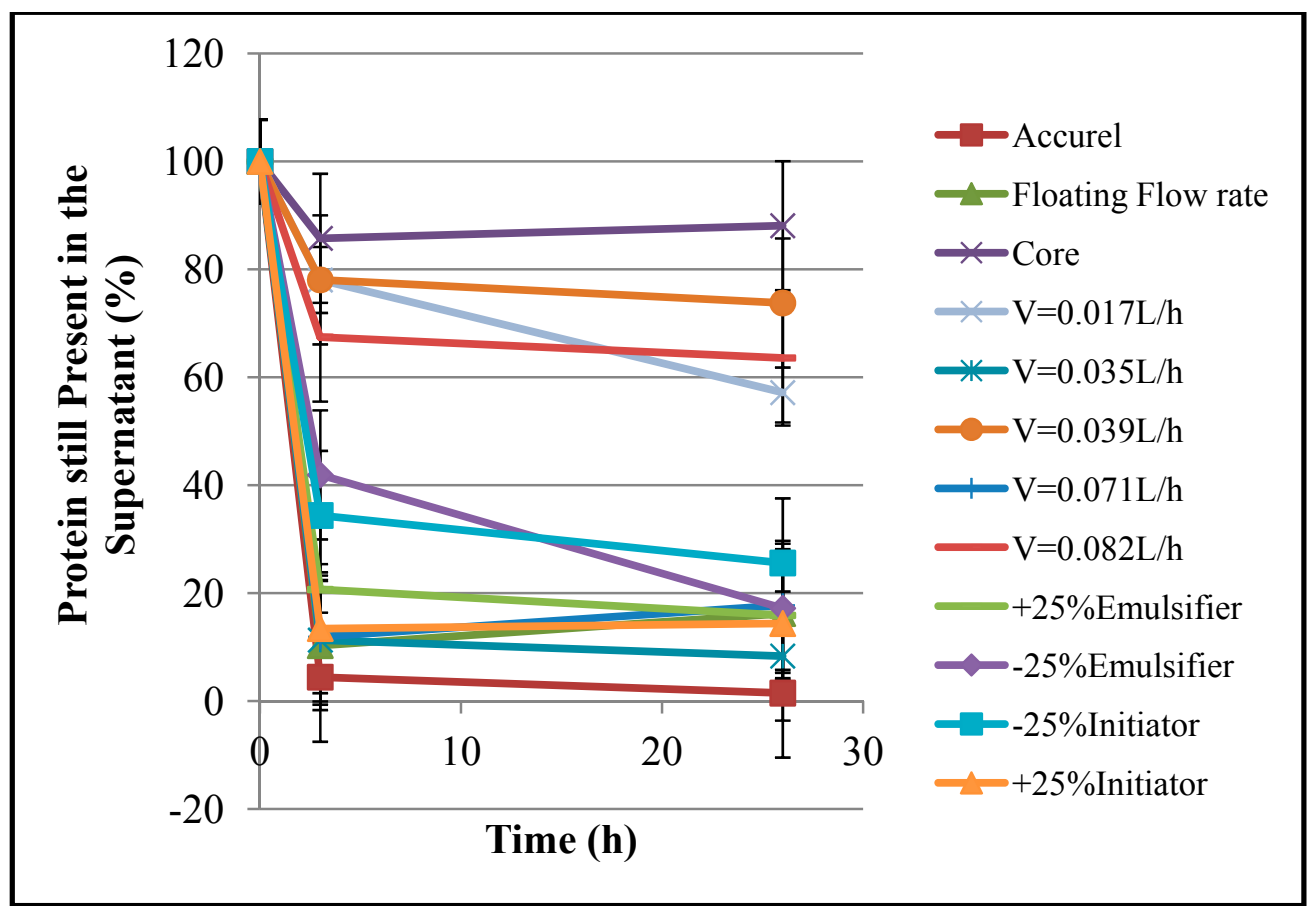

(a) 
Figure 2. Cont.

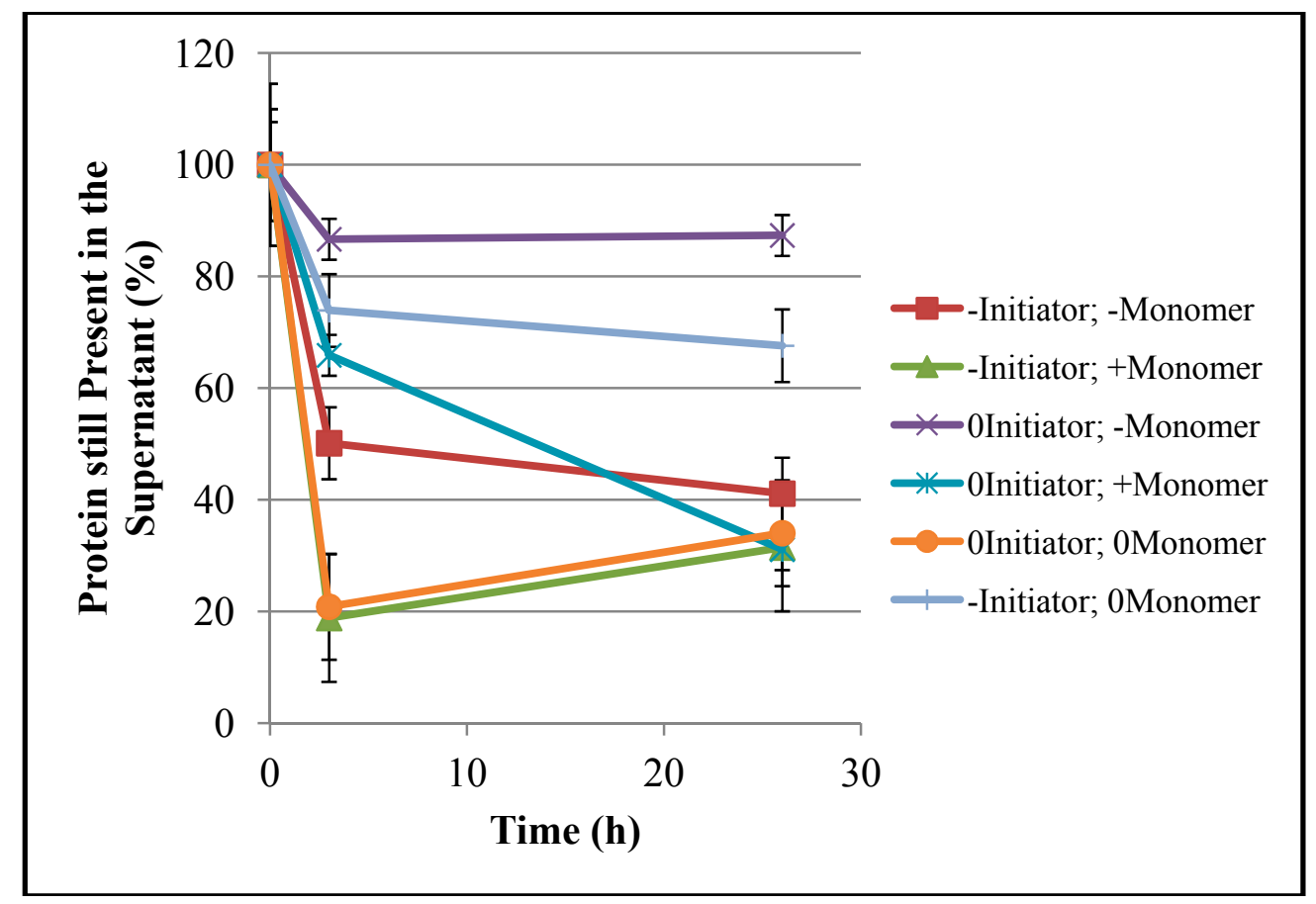

(b)

\subsection{Influence of the Morphology of the Supports on the Immobilization Parameters}

The immobilization parameters obtained for each immobilization experiment are listed in Table 1. The analysis of these parameters is essential for the understanding of the effect of the morphology of the supports on the performances of the produced biocatalysts. As the immobilization experiments were performed at different moments, the initial hydrolytic enzymes activities are not equal, but always in the vicinities of $100 \mathrm{U}$.

Table 1. Immobilization parameters obtained for the different immobilization supports.

\begin{tabular}{cccccccc}
\hline Supports & $\begin{array}{c}\text { Ue } \\
\text { (U/gsupport) }\end{array}$ & $\begin{array}{c}\text { Ahid } \\
\text { (U/gbio) }\end{array}$ & $\begin{array}{c}\text { Aester } \\
\text { (U/gbio) }\end{array}$ & $\begin{array}{c}\text { Utheo } \\
\text { (U/gsupport) }\end{array}$ & H (\%) & $\begin{array}{c}\text { Ra } \\
(\%)\end{array}$ & $\begin{array}{c}\text { Protein Concentration on } \\
\text { the Support (mg/gsupport) }\end{array}$ \\
\hline Accurel & 91.8 & $0.7 \pm 0.7$ & $616 \pm 166$ & 91.4 & 99.5 & 0.7 & 4.5 \\
Carrier 1 & 127.0 & $2.3 \pm 0.6$ & $588 \pm 307$ & 126.0 & 99.2 & 1.8 & 5.2 \\
Carrier 2 & 84.4 & $5.7 \pm 2.4$ & $133 \pm 111$ & 32.4 & 38.4 & 17.6 & 0.5 \\
Carrier 3 & 116.8 & $4.2 \pm 2.5$ & $311 \pm 80$ & 115.0 & 98.4 & 3.6 & 5.3 \\
Carrier 4 & 80.7 & $2.2 \pm 1.1$ & $56 \pm 21$ & 34.8 & 43.1 & 6.3 & 1.0 \\
Carrier 5 & 91.6 & $0.9 \pm 0.9$ & $193 \pm 40$ & 85.6 & 93.5 & 1.1 & 3.7 \\
Carrier 6 & - & - & - & - & - & - & - \\
Carrier 7 & 84.2 & $0.9 \pm 0.4$ & $104 \pm 26$ & 21.9 & 26.0 & 3.9 & 1.5 \\
Carrier 12 & 73.5 & $7.1 \pm 2.4$ & $828 \pm 397$ & 69.3 & 94.2 & 10.3 & 1.5 \\
Carrier 8 & 82.1 & $1.9 \pm 0.3$ & $315 \pm 59$ & 77.3 & 94.2 & 2.4 & 4.3 \\
Carrier 9 & 82.1 & $1.1 \pm 0.5$ & $175 \pm 3$ & 76.5 & 93.2 & 1.5 & 4.3 \\
Carrier 10 & 83.5 & $2.1 \pm 0.3$ & $186 \pm 43$ & 71.7 & 85.9 & 2.9 & 3.9 \\
Carrier 11 & 83.0 & $1.0 \pm 0.3$ & $165 \pm 104$ & 80.8 & 97.4 & 1.2 & 4.5 \\
\hline
\end{tabular}


Table 1. Cont.

\begin{tabular}{lccccccc}
\hline Supports & $\begin{array}{c}\text { Ue } \\
\text { (U/gsupport) }\end{array}$ & $\begin{array}{c}\text { Ahid } \\
\text { (U/gbio) }\end{array}$ & $\begin{array}{c}\text { Aester } \\
\text { (U/gbio) }\end{array}$ & $\begin{array}{c}\text { Utheo } \\
\text { (U/gsupport) }\end{array}$ & $\begin{array}{c}\text { H } \\
(\%)\end{array}$ & $\begin{array}{c}\text { Ra } \\
(\%)\end{array}$ & $\begin{array}{c}\text { Protein Concentration on } \\
\text { the Support (mg/gsupport) }\end{array}$ \\
\hline Carrier 13 & 76.0 & $3.5 \pm 0.6$ & $929 \pm 231$ & 70.2 & 92.5 & 4.9 & 2.1 \\
Carrier 14 & 80.6 & $1.6 \pm 0.5$ & $364 \pm 156$ & 73.3 & 90.9 & 2.2 & 2.4 \\
Carrier 15 & 81.4 & $4.5 \pm 1.0$ & $234 \pm 90$ & 17.6 & 21.6 & 25.7 & 0.5 \\
Carrier 16 & 81.6 & $4.4 \pm 1.0$ & $512 \pm 197$ & 64.2 & 78.6 & 6.8 & 2.4 \\
Carrier 17 & 112.0 & $3.4 \pm 1.1$ & $565 \pm 71$ & 97.9 & 87.4 & 3.5 & 2.7 \\
Carrier 18 & 111.5 & $3.0 \pm 0.01$ & $90 \pm 55$ & 37.4 & 33.5 & 7.9 & 1.3 \\
\hline
\end{tabular}

In order to facilitate the understanding of the relationship between the morphological properties of the supports and the immobilization parameters, some graphs were prepared as shown in Figure 3. It is possible to observe in Figure 3a that there exists a relatively low minimum specific area value that virtually guarantees the complete adsorption of the initial amount of protein, indicating the good interaction of the enzyme and the support surfaces. It can also be observed in Figure $3 \mathrm{~b}$ that the increase of the specific area causes the reduction of the retention of activity, due to the accumulation of polymer in the shell, indicating the existence of diffusional limitation effects. Diffusional limitation is probably related to the high reaction rates, as reaction dynamics is very fast and steady state concentration profiles are not likely to be attained. The reduction of retention of activity can also be related to the formation of longer pores in the shell, as discussed in the literature [15], as the presence of long pores in the shell can lead to low accessibility of reagents present in the aqueous media due to the hydrophobicity of the support.

It can be noted in Figure $3 \mathrm{c}$ that there also is a minimum value of volume of pores required for almost complete adsorption of protein and that the retention of activity decreases with the increase of the volume of pores, as shown in Figure 3d. The effects caused by the specific area and the volume of pores on the immobilization parameters are similar because these two morphological properties respond primarily to the accumulation of polymer in the shell, so that they should be regarded as redundant dependent variables.

Figure 3e,f apparently indicate that the average pore diameter does not affect the yield of immobilization and retention of activity. According to Mojovic et al., the characteristic diameter of lipases is close to $70 \AA$ [37]. Table 1 and Figure 3e,f show that the average pore diameters of the supports were significantly larger than the characteristic size of the enzyme, which can probably explain the secondary effect of average pore diameters on the immobilization parameters. Although three samples apparently showed a distinct behavior, this can probably be associated with the low specific areas of these supports, not considered in Figure 3e,f. Bayne et al., also noticed the lack of significant correlation between the pore diameters and the retention of activity and between the pore characteristics and the protein loading level in supports of different compositions, for large pore diameters, as observed in the present manuscript [38]. 
Figure 3. Effect of morphological properties of the supports on the immobilization parameters: (a) specific area $v s$. yield of immobilization; (b) specific area $v s$. retention of activity; (c) volume of pores vs. yield of immobilization; (d) volume of pores vs. retention of activity; (e) average pore diameter vs. yield of immobilization; (f) average pore diameter $v s$. retention of activity.

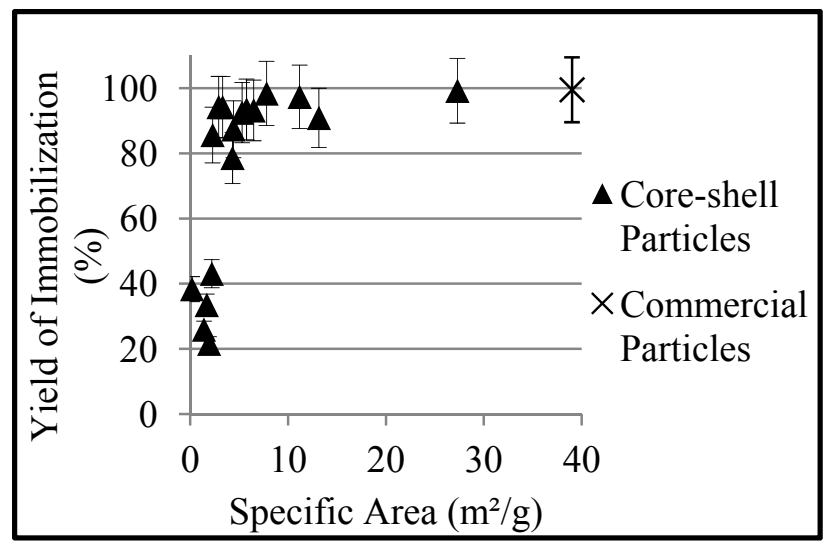

(a)

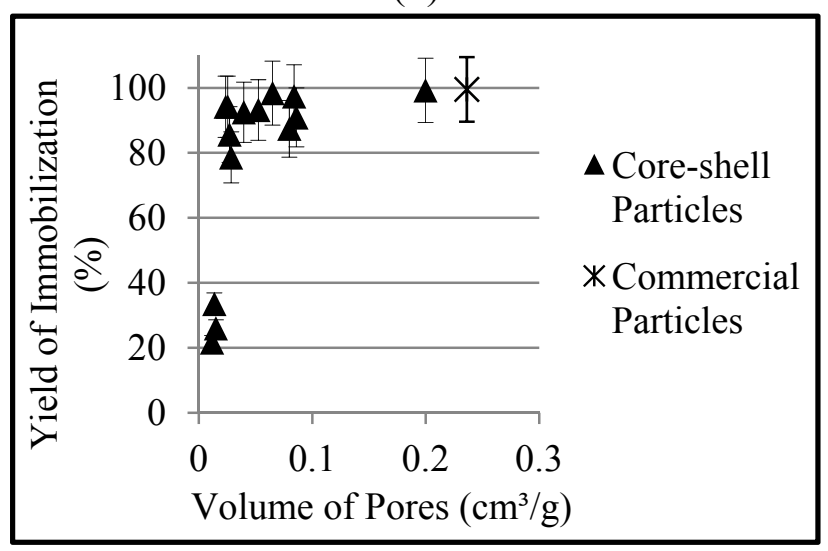

(c)

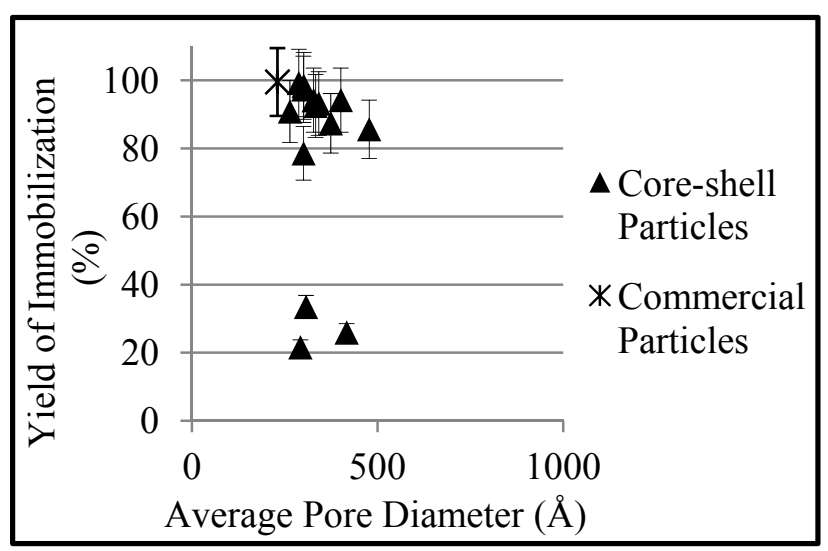

(e)

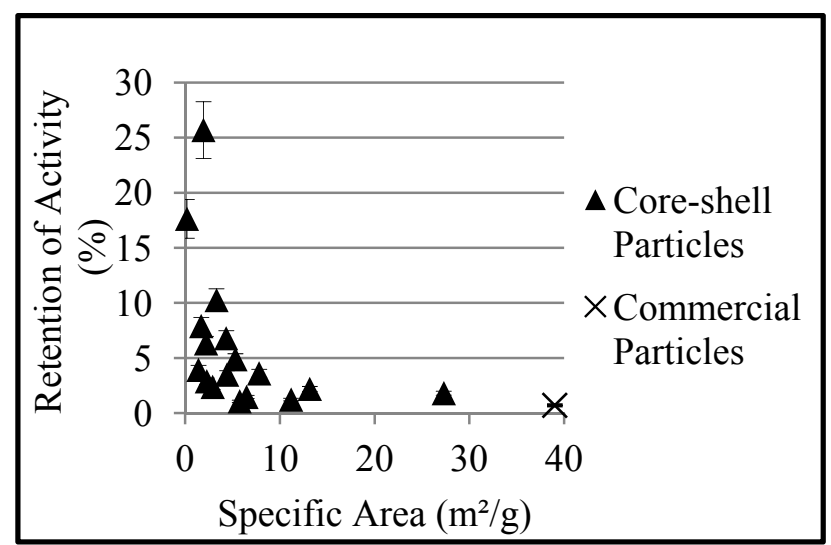

(b)

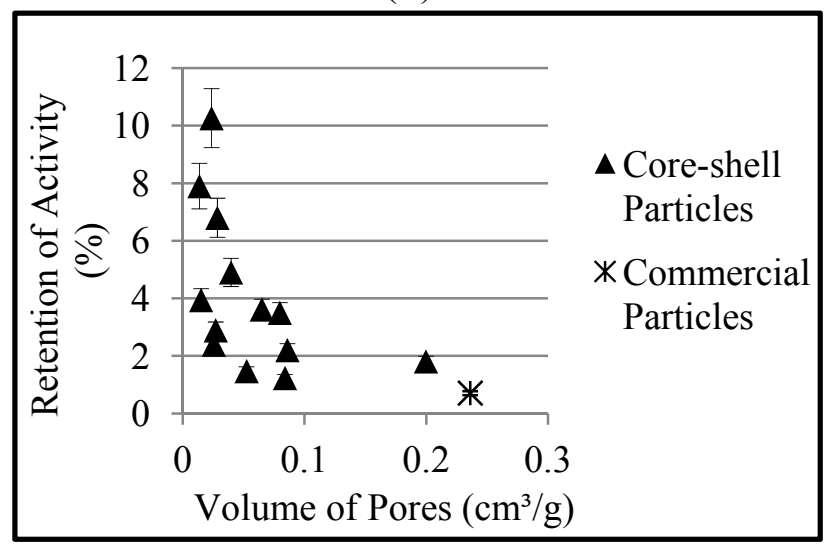

(d)

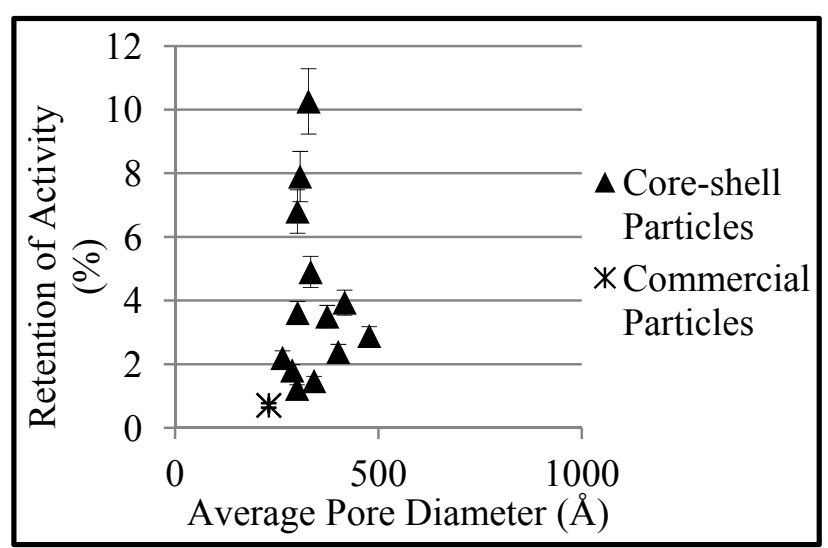

(f) 


\subsection{Influence of the Morphology of the Supports on the Hydrolytic Activities of the Biocatalysts}

According to Table 1, it is possible to note that the absolute values of the hydrolytic activities of the biocatalysts were low. This could already be expected because CAL-B is employed mainly to catalyze esterification reactions. Surprisingly, particle cores with very low specific areas presented very high hydrolytic activities. This can be explained in terms of the high exposure of adsorbed enzyme molecules to the substrate, as adsorbed enzyme molecules are located essentially on the outer surface of the particle, which substantially minimizes possible diffusion effects. This result supports the idea that mass transfer limitations can control the performances of the produced biocatalysts for the hydrolytic reaction. It is also very important to notice that the majority of the produced biocatalysts exhibited higher hydrolytic activities than the biocatalyst synthesized with the commercial support, indicating that the performances of the produced supports can be regarded as good.

The effects of the morphological properties of the supports on the hydrolytic activity of the biocatalysts are shown in Figure 4. It is possible to observe the decrease of hydrolytic activity with the specific area and volume of pores, while the average pore diameter apparently does not affect the hydrolytic activity of the biocatalyst, for the reasons presented before.

It must be noted that the increase of the monomer feed flowrate caused the decrease of the hydrolytic activities of the biocatalysts, probably because of the decrease of the amount of enzyme adsorbed onto de supports (due to the lower specific areas) and the increase of the diffusional limitation effects (as the increase of monomer feed flowrate accelerates particle agglomeration on the shell). On the other hand, the increase of the amount of emulsifier caused the increase of the hydrolytic activity, while the increase of the amount of initiator caused the decrease of the hydrolytic activity of the biocatalyst. Both variables affect the rate of formation and the diameters of the emulsified particles in a complex manner, also affecting the hydrophobicity of the particle surfaces. Therefore, it is possible to note that the polymerization conditions and the emulsion recipe do affect the immobilization parameters and the final biocatalyst performance, as presented below with more detail.

Figure 4. Effect of morphological properties of the supports on the hydrolytic activities of the produced biocatalysts: (a) Specific area; (b) Volume of pores; (c) Average pore diameter.

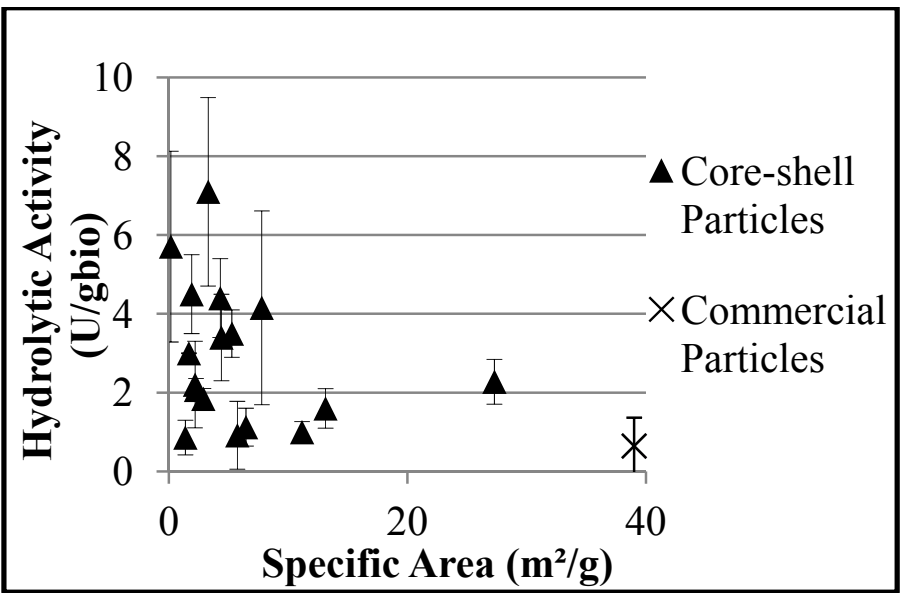

(a) 
Figure 4. Cont.

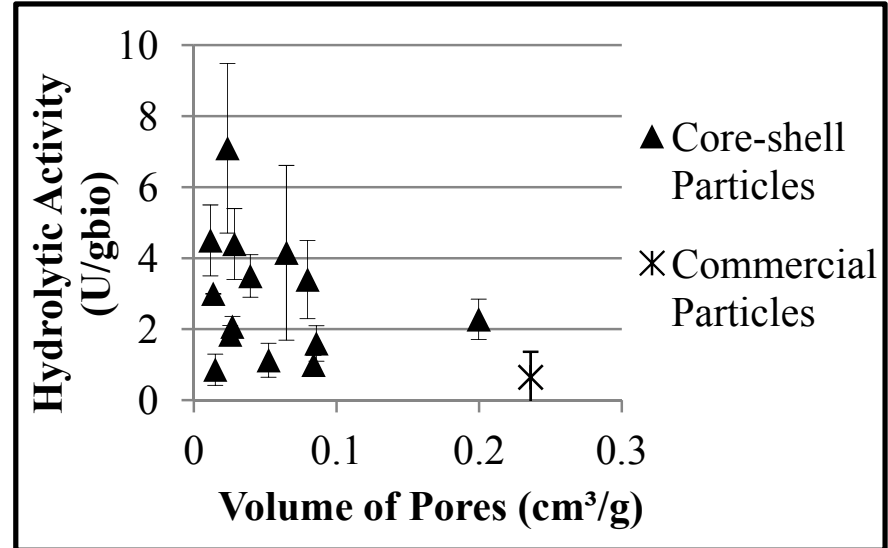

(b)

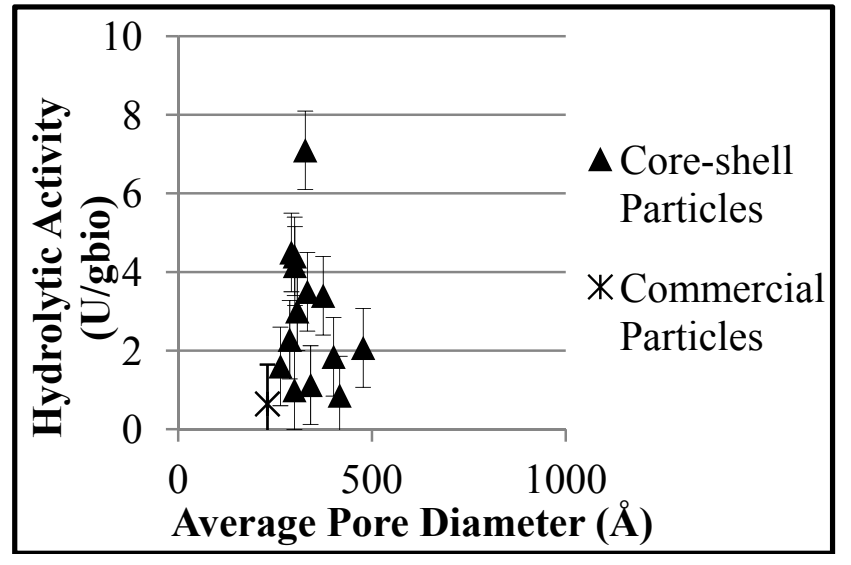

(c)

\subsection{Influence of the Morphology of the Supports on the Esterification Activities of the Biocatalysts}

The esterification activities of the biocatalysts are also shown in Table 1. As mentioned previously, the absolute values of the esterification activities are much more significant than the hydrolytic activities. Particularly, core particles presented very low esterification activities, given the lower amounts of adsorbed enzyme. It is important to observe that diffusional effects are expected to be more intense in hydrolytic reactions, due to the higher rates of reaction. Esterification reactions are less intense and take place for longer periods of time, which probably can explain the differences observed in both cases. Once more, it is important to emphasize that many produced biocatalysts exhibited higher esterification activities than the biocatalyst synthesized with the commercial support, indicating that the performances of the produced supports can be regarded as good.

Figure 5 shows the effect of morphological properties of the supports on the esterification activities of the obtained biocatalysts. The increase of the specific area (and of the volume of pores) tends to increase of the esterification activities, due to the higher amounts of enzyme retained by the supports. Apparently, as observed previously for the hydrolytic activity, the average pore diameter does not affect the esterification activity of the biocatalyst.

Figure 5. Effect of morphological properties of the supports on the esterification activities of the produced biocatalysts: (a) specific area; (b) volume of pores and (c) average pore diameter.

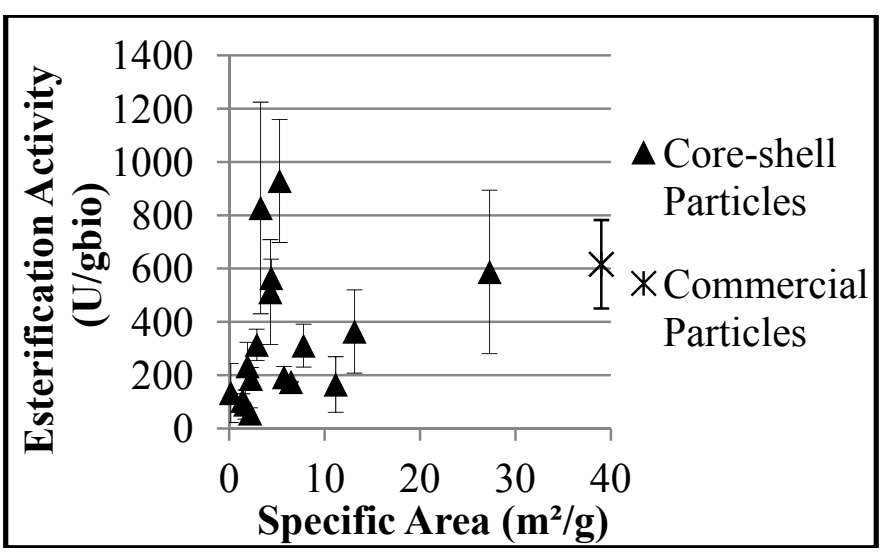

(a)

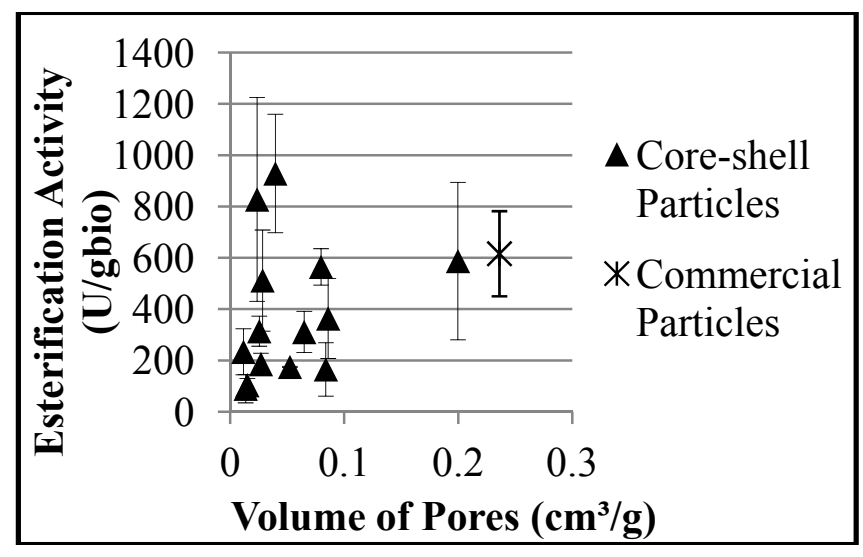

(b) 
Figure 5. Cont.

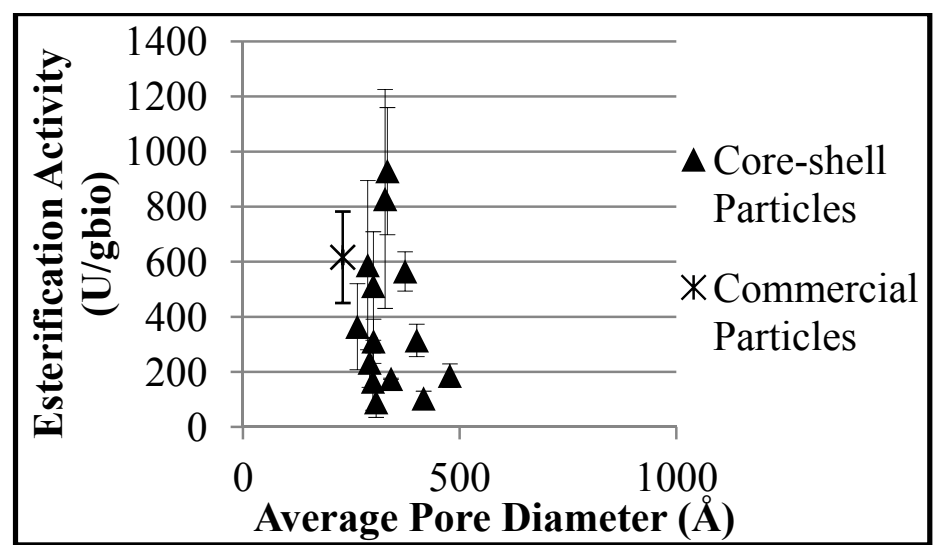

(c)

The increase of the monomer feed flowrate caused the decrease of the esterification activities of the produced biocatalysts, as also observed previously for hydrolytic activities and reinforcing that diffusional limitations induced by thicker polymer shells can control the enzymatic activities of the biocatalysts. On the other hand, the increase of emulsifier amounts caused the increase of the esterification activity, while variation of the initiator amounts did not affect the esterification activity of the biocatalysts very significantly. As already said, both variables affect the rate of formation and the diameters of the emulsified particles in a complex manner, also affecting the hydrophobicity of the particle surfaces, which can certainly affect the final performances of the biocatalysts. It is also possible to notice that the increase of the amount monomer caused the increase of esterification activities of the biocatalysts. This can probably be explained in terms of the increase of protein retained on the supports with the increase of the amount of monomer, given the higher specific areas of the support. Once more, it is possible to note that the polymerization conditions and the emulsion recipe do affect the immobilization parameters and the final biocatalyst performance.

\subsection{Empirical Models}

Based on the previous results, empirical models were developed to describe observed hydrolytic and esterification activities of the biocatalysts as functions of the morphological properties of the supports. It is important to emphasize that empirical models built as functions of the operation variables of the polymerization process led to worse quantitative results, when compared to empirical models built as functions of the morphological properties of the support. This probably indicates that the morphological properties exert a much more significant effect on the final biocatalysts performances than the polymerization operation conditions, although morphological properties resulted from reaction operation conditions. For this reason, empirical models are presented only for enzymatic activities as functions of the morphological properties of the supports.

The empirical model that describes the hydrolytic activity is shown in Table 2. It can be observed that the performance of the hydrolytic model is satisfactory, with correlation coefficient of 0.84 . Figure 6 illustrates the relationship between the experimental hydrolytic activities of the biocatalysts and the hydrolytic activity calculated by the model, showing that calculated errors are similar to observed experimental fluctuations. According to the empirical model, a maximum hydrolytic activity value is 
reached as the specific areas of the supports increase. This result corroborates the idea that diffusional limitation effects influence the performances of the biocatalysts, probably because of the high reaction rates, as already discussed. As shown before, average pore diameters exert secondary effects on the hydrolytic activities, through the nonlinear interaction effects (parameters b12 and b13). Although values of specific areas and volumes of pores are correlated, inclusion of both variables on the model was necessary, indicating that these variables respond independently to other process perturbations.

Table 2. Empirical model that describes the hydrolytic activity of the produced biocatalysts.

\begin{tabular}{cccccc}
\hline \multicolumn{6}{c}{ Equation } \\
\hline \multicolumn{7}{c}{$\mathrm{A}_{\text {hid }}=\mathrm{a} 1 \times \mathrm{S}_{\text {esp }}+\mathrm{a} 3 \times \mathrm{V}_{\text {esp }}+\mathrm{b} 11 \times \mathrm{S}_{\text {esp }} \times \mathrm{S}_{\text {esp }}+\mathrm{b} 12 \times \mathrm{V}_{\text {esp }} \times \mathrm{D}_{\mathrm{p}}+\mathrm{b} 13 \times \mathrm{S}_{\text {esp }} \times \mathrm{D}_{\mathrm{p}}$} \\
& Estimated Parameters $(\mathrm{R}=0.84 ;$ Degree of Freedom $=6)$ \\
\hline Parameters & $\mathrm{a} 1\left(\mathrm{U} \cdot \mathrm{m}^{-2}\right)$ & $\mathrm{a} 3\left(10^{6} \cdot \mathrm{U} \cdot \mathrm{m}^{-3}\right)$ & $\mathrm{b} 11\left(\mathrm{U} \cdot \mathrm{g} \cdot \mathrm{m}^{-4}\right)$ & $\mathrm{b} 12\left(10^{16} \cdot \mathrm{U} \cdot \mathrm{m}^{-4}\right)$ & $\mathrm{b} 13\left(10^{10} \cdot \mathrm{U} \cdot \mathrm{m}^{-3}\right)$ \\
Estimated Values & 8.51 & -532.97 & -0.16 & 1.52 & -0.02 \\
Standard Errors & 2.20 & 239.72 & 0.03 & 0.65 & 0.01 \\
Significance & 0.992 & 0.932 & 0.999 & 0.942 & 0.986 \\
\hline
\end{tabular}

Notes: where $A_{\text {hid }}$ is the hydrolytic activity of the immobilized enzymes (U/gbio); $S_{\text {esp }}$ is the specific area of the supports $\left(\mathrm{m}^{2} / \mathrm{g}\right)$; $D_{\mathrm{p}}$ is the average pore diameter $(\AA)$; $\mathrm{V}_{\text {esp }}$ is the volume of pores of the supports $\left(\mathrm{cm}^{3} / \mathrm{g}\right)$.

Figure 6. Relationship between the experimental hydrolytic activities and the hydrolytic activities predicted by the empirical model.

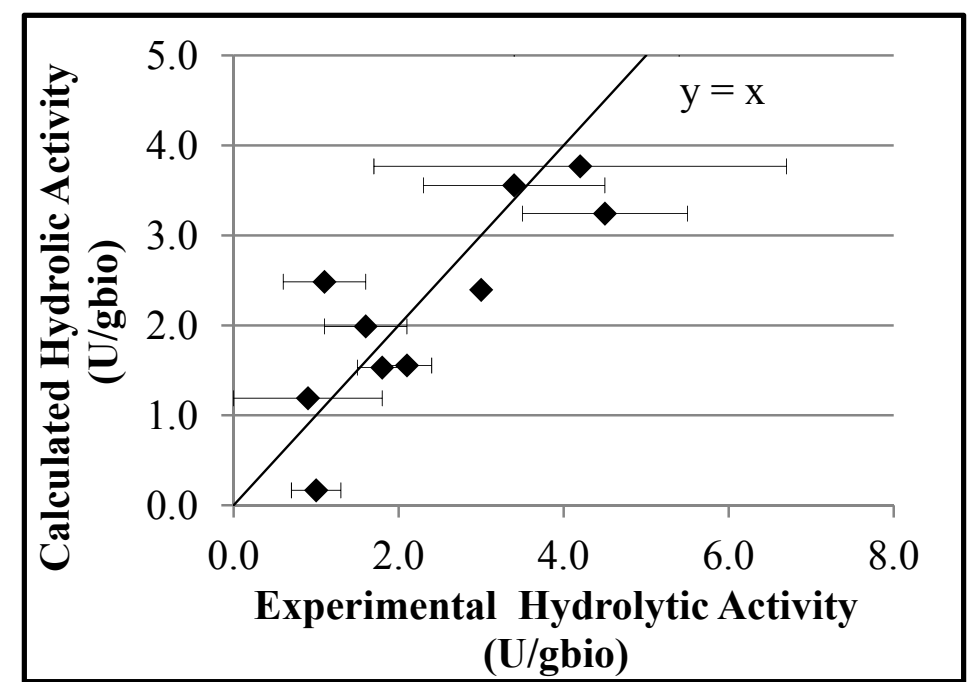

The empirical model developed to describe the esterification activities is shown in Table 3 and Figure 7. As a whole, the model performance can be regarded as satisfactory $(\mathrm{R}=0.88)$, despite the larger number of parameters and the very poor significance of the calculated parameters. The poor significance of model parameters is explained by the very small number of degrees of freedom of the resulting model and the natural fluctuations of the available experimental data. On the other hand, removal of model parameters can lead to dramatic drop of the correlation coefficient. This probably indicates that additional factors also affect the esterification activities of final biocatalysts, although not considered in the proposed empirical model. For instance, the existence of diffusional limitation effects can also indicate that the enzyme molecule is subject to conformational modification in the different biocatalysts, which is not considered here. Besides, as emulsifier and initiator molecules can 
change the hydrophobicity of the emulsified polymer particles that form the shell, this effect should also be investigated in future works.

Table 3. Empirical model that describes the esterification activity of the produced biocatalysts.

\begin{tabular}{|c|c|c|c|c|}
\hline \multicolumn{5}{|c|}{ Equation } \\
\hline \multicolumn{5}{|c|}{$\begin{array}{c}A_{\text {ester }}=\mathrm{a} 0+\mathrm{a} 1 \times \mathrm{S}_{\text {esp }}+\mathrm{a} 2 \times \mathrm{D}_{\mathrm{p}}+\mathrm{a} 3 \times \mathrm{V}_{\text {esp }}+\mathrm{b} 11 \times \mathrm{S}_{\text {esp }} \times \mathrm{D}_{\mathrm{p}}+\mathrm{b} 12 \times \mathrm{V}_{\text {esp }} \times \mathrm{S}_{\text {esp }}+\mathrm{b} 13 \times \mathrm{V}_{\text {esp }} \times \mathrm{D}_{\mathrm{p}}+\mathrm{c} 12 \times \mathrm{S}_{\text {esp }} \times \mathrm{D}_{\mathrm{p}} \times \mathrm{V}_{\text {esp }} \\
\text { Estimated Parameters }(\mathrm{R}=0.88 ; \text { Degree of Freedom }=3)\end{array}$} \\
\hline & arameters & Estimated Values & Standard Errors & Significance \\
\hline $\mathrm{a} 0$ & $\left(\mathrm{U} \cdot \mathrm{g}^{-1}\right)$ & -19.5 & 1204.1 & 0.012 \\
\hline $\mathrm{a} 1$ & $\left(\mathrm{U} \cdot \mathrm{m}^{-2}\right)$ & 652.6 & 850.3 & 0.501 \\
\hline $\mathrm{a} 2$ & $\left(10^{10} \mathrm{U} \cdot(\mathrm{g} \cdot \mathrm{m})^{-1}\right)$ & -0.2 & 3.6 & 0.032 \\
\hline $\mathrm{a} 3$ & $\left(10^{6} \mathrm{U} \cdot \mathrm{m}^{-3}\right)$ & -39898.7 & 58152.5 & 0.458 \\
\hline b11 & $\left(10^{10} \mathrm{U} \cdot \mathrm{m}^{-3}\right)$ & -1.7 & 2.4 & 0.426 \\
\hline b12 & $\left(10^{6} \mathrm{U} \cdot \mathrm{g} \cdot \mathrm{m}^{-5}\right)$ & -1977.8 & 7867.3 & 0.182 \\
\hline b13 & $\left(10^{16} \mathrm{U} \cdot \mathrm{m}^{-4}\right)$ & 147.3 & 148.8 & 0.605 \\
\hline $\mathrm{c} 12$ & $\left(10^{16} \mathrm{U} \cdot \mathrm{g} \cdot \mathrm{m}^{-6}\right)$ & 0.4 & 25.3 & 0.011 \\
\hline
\end{tabular}

Notes: where $A_{\text {ester }}$ is the esterification activity of the immobilized enzymes $\left(U / g_{b i o}\right) ; S_{\text {esp }}$ is the specific area of the supports $\left(\mathrm{m}^{2} / \mathrm{g}\right) ; \mathrm{D}_{\mathrm{p}}$ is the average pore diameter $(\AA) ; \mathrm{V}_{\text {esp }}$ is the volume of pores of the supports $\left(\mathrm{cm}^{3} / \mathrm{g}\right)$.

Figure 7. Relationship between the experimental esterification activities and the esterification activities predicted by the empirical model.

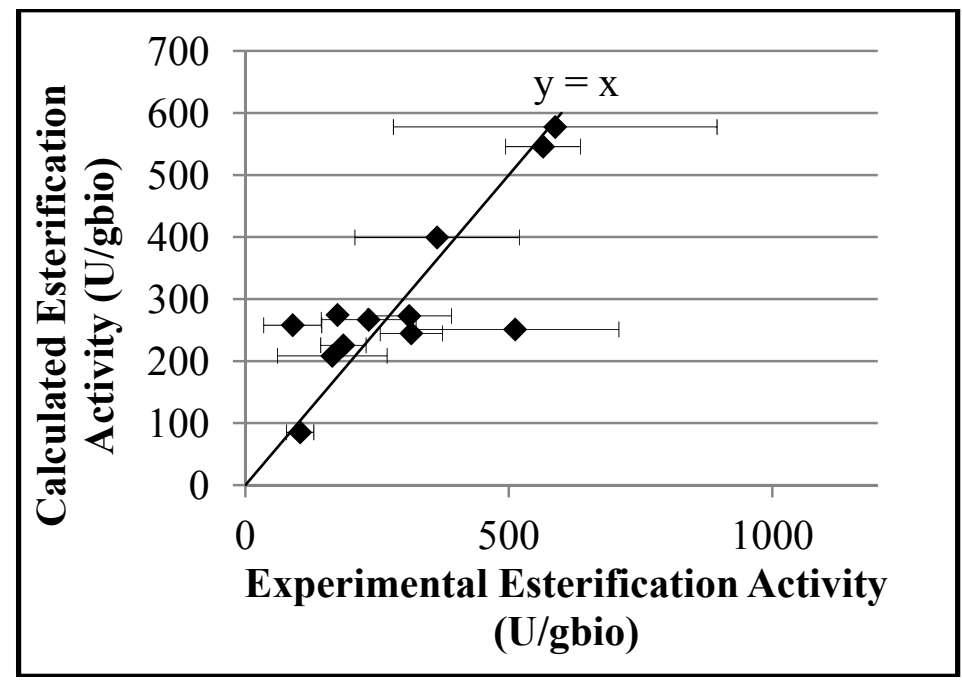

\section{Experimental Section}

\subsection{Materials}

All reactants were used as received, without any purification step. Lipozyme ${ }^{\circledR}$ CALB L, Lipase B from Candida antarctica (CAL-B) was supplied by Novozymes (Bagsvaerd, Denmark) in the soluble form. The substrate used for determination of hydrolytic activities, $p$-nitrophenyl laurate ( $p$-NPL), was purchased from Sigma Aldrich (St. Louis, MO, USA) with minimum purity of 98 wt \%. Ethanol P.A., supplied by Vetec Química Fina (Rio de Janeiro, Brazil), with a minimum purity of $99.8 \mathrm{wt} \%$, was used for washing of the polymer supports and also as substrate in esterification 
reactions. Oleic acid with minimum purity of 98 wt \% was supplied by Vetec Química Fina and was used as substrate in esterification reactions. The commercial polypropylene support Accurel ${ }^{\circledR}$ MP 1000 was supplied by Akzo Nobel Faser AG (Obernburg, Germany) and used as a benchmark support for comparative evaluation of the performances of the synthesized biocatalysts. The Bradford reagent was supplied by BioRad (Hercules, CA, USA). Styrene with minimum purity of $99.5 \mathrm{wt} \%$ used as monomer in polymerization reactions was supplied by Sigma Aldrich (St. Louis, MO, USA). Other reagents and solvents used for product purification and characterization were of analytical grade.

\subsection{Preparation of Core-Shell Polymer Supports}

Core-shell polystyrene supports were produced through simultaneous suspension/emulsion polymerizations. The analyzed polymerization technique comprises two fundamental steps. Initially, the particle cores are formed through standard batch suspension polymerization. After the specified amount of time, the emulsion constituents are added to the reacting medium, forming small particles through emulsion polymerization. The newly formed particles coagulate over the cores produced previously, forming the shell and leading to formation of porous core-shell polymer particles [28,29,39]. It is important to note that the constituents and reaction conditions used in the emulsion polymerization step affect the final morphology of the produced particles [28,29,39].

Combined suspension-emulsion polymerizations were carried out as described in the literature [28,29,39]. Reactions were carried out in an open 1-L jacketed glass reactor (FGG Equipamentos Científicos, São Paulo, Brazil) equipped with a thermostatic bath (Haake Phoenix II model, Thermo Scientific, Karlsruhe, Germany), used to control the reactor temperature (kept at $85{ }^{\circ} \mathrm{C}$ in all experiments), and with a cooling bath (Nova Ética, São Paulo, Brazil), used to control the temperature of the condenser (kept at $10{ }^{\circ} \mathrm{C}$ in all experiments). Styrene was used as monomer in all reactions. Initially, the particle cores were formed through standard batch suspension polymerization by dispersing $100 \mathrm{~g}$ of an organic solution (containing styrene and $3.8 \mathrm{wt} \%$ of the initiator benzoyl peroxide) in $370 \mathrm{~g}$ of an aqueous solution (containing distilled water and $0.80 \mathrm{wt} \%$ of poly(vinyl alcohol), used as stabilizer) through agitation (kept equal to $950 \mathrm{rpm}$ in all runs). After two hours of suspension reaction, the emulsion constituents (styrene monomer and an aqueous solution containing distilled water, $0.13 \mathrm{wt} \%$ of the initiator potassium persulfate and $1 \mathrm{wt} \%$ of lauryl sulfate, used as emulsifier) were added to the reacting medium. In order to control the reaction temperature, part of the emulsion feed (30 $\mathrm{g}$ of monomer and $230 \mathrm{~g}$ of the aqueous solution) was added initially in a single load, while the remaining $70 \mathrm{~g}$ of monomer were added continuously at the specified flow rate. The experimental run was finished after 6 hours of reaction. Supports with distinct properties were synthesized through manipulation of monomer feed flow rates (V), amounts of emulsifier, amounts of initiator and amounts of monomer that were used in the emulsion polymerization.

At the end of the batch, the reactor was cooled down and the obtained particles were filtrated and washed with abundant cold water. Finally, the obtained polymer particles were dried in a vacuum oven at ambient temperature until constant mass. The analyzed experimental design is presented in Table 4. Experiments did not follow a standard factorial design because combination of certain process operation conditions led to massive coagulation of the polymer particles. 
Table 4. Reaction conditions and morphological properties of the produced supports: specific area $\left(\mathrm{S}_{\text {esp }}\right)$, volume of pores $\left(\mathrm{V}_{\text {esp }}\right)$ and average pore diameter $\left(\mathrm{D}_{\mathrm{p}}\right)$. Variations regard the emulsion polymerization step and used recipe defined in Section 3.2 as reference.

\begin{tabular}{|c|c|c|c|c|c|}
\hline Reaction & Legend & Graph Legend & $\begin{array}{l}\text { Sesp } \\
\left(\mathrm{m}^{2} / \mathrm{g}\right)\end{array}$ & $\begin{array}{c}\text { Vesp } \\
\left(\mathrm{cm}^{3} / \mathrm{g}\right)\end{array}$ & $\begin{array}{l}\text { Dp } \\
(\AA)\end{array}$ \\
\hline $1^{1}$ & Floating Flow Rate & Floating Flow Rate & 27.3 & 0.20 & 287.6 \\
\hline $2^{2}$ & Core & Core & 0.2 & - & - \\
\hline 3 & Reference; $\mathrm{V}=0.035 \mathrm{~L} / \mathrm{h}$ & $\mathrm{V}=0.035 \mathrm{~L} / \mathrm{h}$ & 7.8 & 0.06 & 300.9 \\
\hline $4^{3}$ & Reference; $\mathrm{V}=0.039 \mathrm{~L} / \mathrm{h}$ & $\mathrm{V}=0.039 \mathrm{~L} / \mathrm{h}$ & 2.2 & - & - \\
\hline $5^{3}$ & Reference; $\mathrm{V}=0.071 \mathrm{~L} / \mathrm{h}$ & $\mathrm{V}=0.071 \mathrm{~L} / \mathrm{h}$ & 5.7 & - & - \\
\hline $6^{4}$ & Reference; $\mathrm{V}=0.127 \mathrm{~L} / \mathrm{h}$ & $\mathrm{V}=0.127 \mathrm{~L} / \mathrm{h}$ & - & - & - \\
\hline $7^{3}$ & Reference; $\mathrm{V}=0.082 \mathrm{~L} / \mathrm{h}$ & $\mathrm{V}=0.082 \mathrm{~L} / \mathrm{h}$ & 1.4 & 0.01 & 416.4 \\
\hline 8 & $+25 \%$ Emulsifier; $\mathrm{V}=0.035 \mathrm{~L} / \mathrm{h}$ & $+25 \%$ Emulsifier & 2.9 & 0.03 & 400.8 \\
\hline 9 & $-25 \%$ Emulsifier; $\mathrm{V}=0.035 \mathrm{~L} / \mathrm{h}$ & $-25 \%$ Emulsifier & 6.5 & 0.05 & 341.4 \\
\hline 10 & $-25 \%$ Initiator; $\mathrm{V}=0.035 \mathrm{~L} / \mathrm{h}$ & $-25 \%$ Initiator & 2.3 & 0.03 & 477.0 \\
\hline 11 & $+25 \%$ Initiator; $\mathrm{V}=0.035 \mathrm{~L} / \mathrm{h}$ & $+25 \%$ Initiator & 11.2 & 0.08 & 299.7 \\
\hline 12 & Reference; $\mathrm{V}=0.017 \mathrm{~L} / \mathrm{h}$ & $\mathrm{V}=0.017 \mathrm{~L} / \mathrm{h}$ & 3.3 & 0.02 & 327.6 \\
\hline 13 & $\begin{array}{c}-25 \% \text { Initiator; }-50 \% \text { Monomer; } \\
\mathrm{V}=0.035 \mathrm{~L} / \mathrm{h}\end{array}$ & $\begin{array}{l}\text {-Initiator; } \\
\text {-Monomer }\end{array}$ & 5.3 & 0.04 & 333.0 \\
\hline 14 & $\begin{array}{c}-25 \% \text { Initiator; }+50 \% \text { Monomer; } \\
\mathrm{V}=0.035 \mathrm{~L} / \mathrm{h}\end{array}$ & $\begin{array}{l}\text {-Initiator; } \\
\text { +Monomer }\end{array}$ & 13.1 & 0.09 & 263.7 \\
\hline 15 & $-50 \%$ Monomer; $\mathrm{V}=0.035 \mathrm{~L} / \mathrm{h}$ & $\begin{array}{l}0 \text { Initiator; } \\
\text {-Monomer }\end{array}$ & 1.9 & 0.01 & 291.8 \\
\hline 16 & $+50 \%$ Monomer; $\mathrm{V}=0.035 \mathrm{~L} / \mathrm{h}$ & $\begin{array}{l}0 \text { Initiator; } \\
+ \text { Monomer }\end{array}$ & 4.3 & 0.03 & 300.4 \\
\hline 17 & Reference; $\mathrm{V}=0.035 \mathrm{~L} / \mathrm{h}$ & $\begin{array}{l}0 \text { Initiator; } \\
0 \text { Monomer }\end{array}$ & 4.4 & 0.08 & 373.7 \\
\hline 18 & $-25 \%$ Initiator; $\mathrm{V}=0.035 \mathrm{~L} / \mathrm{h}$ & $\begin{array}{l}\text {-Initiator; } \\
0 \text { Monomer }\end{array}$ & 1.7 & 0.01 & 306.9 \\
\hline- & Commercial Support & Accurel & 39 & 0.24 & 230.0 \\
\hline
\end{tabular}

Notes: ': Monomer feed rate was allowed to fluctuate around reference; ${ }^{2}$ : A shell was not formed;

3: Experiments performed for analysis of the maximum allowed monomer feed rate; ${ }^{4}$ : Massive agglomeration of particles, characterizing a maximum limit for monomer feed rate.

\subsection{Characterization of Supports Morphology}

In order to determine the specific area, the average pore diameter and the volume of pores of the produced core-shell particles, a standard BET surface analyzer was used (ASAP 2020 model, supplied by Micromeritics, Norcross, GA, USA). This rather standard characterization technique is based on the adsorption of nitrogen on the surface of the particles, as described in details elsewhere [2,28-30]. Prior to analyses, samples were pretreated under vacuum at $60{ }^{\circ} \mathrm{C}$. Properties of the obtained supports (specific area, volume of pores and average pore diameter) are also shown in Table 4. Figure 8 
illustrates the morphological aspect of the produced particles. The commercial support, Accurel ${ }^{\circledR}$ MP1000, was also characterized at similar conditions in order to provide reference values for evaluation of the performance of the obtained core-shell particles. As observed experimentally, the analyzed Accurel $^{\circledR}$ MP1000 samples presented specific area of $39 \mathrm{~m}^{2} / \mathrm{g}$, average pore diameter of $230 \AA$ and volume of pores of $0.236 \mathrm{~cm}^{3} / \mathrm{g}$.

Figure 8. Morphological aspect of the produced supports: (a) cores and (b) core-shell particles.

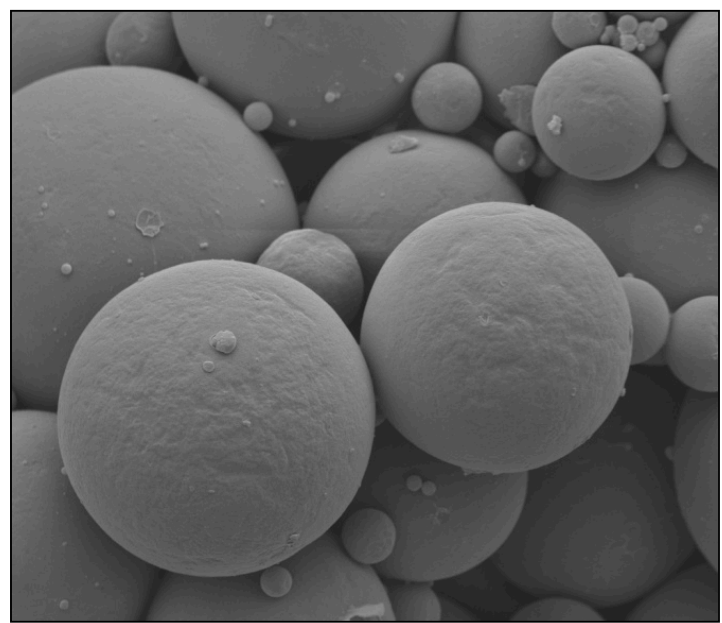

(a)

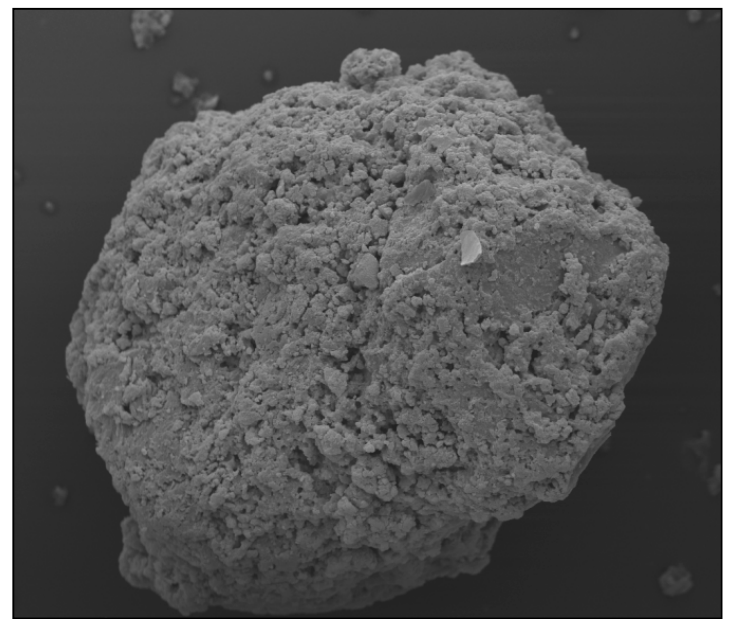

(b)

\subsection{Immobilization Procedure}

The immobilization procedure used here and definition of the immobilization parameters are described in detail elsewhere [2,40-42]. Firstly, the supports were washed in order to eliminate possible residual monomer and to facilitate the penetration of the aqueous enzyme into the porous particles during the enzymatic immobilization. Initially, $10 \mathrm{~mL}$ of ethanol were added to $1 \mathrm{~g}$ of dry support. After $30 \mathrm{~min}$, particles were filtrated and $10 \mathrm{~mL}$ of distilled water were added. After $10 \mathrm{~min}$, particles were filtrated again and washed with abundant distilled water. Finally, the supports were washed with sodium phosphate buffer $(5 \mathrm{mM}, \mathrm{pH}=7.0)$ and kept in the refrigerator $\left(17^{\circ} \mathrm{C}\right)$ until immobilization.

Cunha observed pronounced decrease of the retention of hydrolytic activity when the hydrolytic activity of the enzyme solution was increased from $100 \mathrm{U}$ to $200 \mathrm{U}$ in presence of $1 \mathrm{~g}$ of support, using $p$-NPL as substrate (activities are described in the next sections) [40]. For this reason, the initial hydrolytic activity of the enzymatic solution was kept equal to $100 \mathrm{U}$ in all immobilization experiments and in presence of $1 \mathrm{~g}$ of support. In order to do that, the commercial enzyme solution was dissolved in sodium phosphate buffer $(5 \mathrm{mM})$ in order to obtain the desired enzymatic activity of $100 \mathrm{U}$. The immobilization process was initiated by adding $10 \mathrm{~mL}$ of the enzymatic solution with total hydrolytic activity of $100 \mathrm{U}$ to $1 \mathrm{~g}$ of treated and washed support. The immobilization proceeded for $26 \mathrm{~h}$ under mild stirring at $4{ }^{\circ} \mathrm{C}$. During immobilization, aliquots of $150 \mu \mathrm{L}$ were collected $(0,30 \mathrm{~min}$, $1 \mathrm{~h}, 3 \mathrm{~h}, 6 \mathrm{~h}, 26 \mathrm{~h}$ ) for evaluation of the hydrolytic activity of the aqueous phase, using $p$-NPL as substrate $[2,40-42]$. Finally, the obtained biocatalyst was dried in desiccators for one week and stored in a refrigerator $\left(17^{\circ} \mathrm{C}\right)$. It is important to mention that some measurements were performed in 
triplicate and that the experimental errors of hydrolytic activities were calculated with a confidence level of $95 \%$.

\subsection{Hydrolytic Activity of Biocatalysts}

The biocatalysts were characterized in terms of the hydrolytic activity. Hydrolysis reactions were carried out in batch mode. Initially, $9 \mathrm{~mL}$ of sodium phosphate buffer $(25 \mathrm{mM}, \mathrm{pH}=7.0)$ and $1 \mathrm{~mL}$ of the substrate solution were added to a reactor. Then, approximately $10 \mathrm{mg}$ of the biocatalyst were added to the reactor, initiating the hydrolysis reaction. Each reaction was conducted under mild stirring at $30{ }^{\circ} \mathrm{C}$. Aliquots of $700 \mu \mathrm{L}$ were collected during the batch for approximately $6 \mathrm{~min}$. The absorbance of each aliquot was analyzed in a spectrophotometer (UV-1800 model, supplied by Shimadzu, Kyoto, Japan) at $30{ }^{\circ} \mathrm{C}$ at the wavelength of $412 \mathrm{~nm}$. It is important to mention that experiments were analyzed in triplicates and that the experimental errors of hydrolytic activities were calculated with confidence level of $95 \%$. It is important to note that one unit of enzymatic activity ( 1 IU or $1 \mathrm{U}$ ) corresponds to the amount of enzyme necessary to produce $1 \mu \mathrm{mol}$ of $p$-nitrophenol per minute under the described operating conditions. It is also important to mention that the expression $\mathrm{U} / \mathrm{g}_{\text {support }}$ is related to the enzymatic activity associated to $1 \mathrm{~g}$ of polymer support and that the expression $\mathrm{U} / \mathrm{g}_{\text {bio }}$ corresponds to the enzymatic activity of $1 \mathrm{~g}$ of biocatalyst, after immobilization of the enzyme.

\subsection{Immobilization Parameters}

The first analyzed immobilization parameter, the enzyme yield of immobilization, was determined as shown in Equation (1):

$$
H=\frac{U_{\text {theo }} \times 100}{U_{e}} ; U_{\text {theo }}=U_{e}-U_{s}
$$

where $H$ is the enzyme yield of immobilization (\%); $U_{\text {theo }}$ is the total immobilized enzyme activity in terms of the amount of support $\left(\mathrm{U} / \mathrm{g}_{\text {support }}\right) ; U_{e}$ is the total enzyme activity of the solution in the beginning of the immobilization process ( $\left.\mathrm{U} / \mathrm{g}_{\text {support }}\right)$ and $U_{s}$ is the total enzyme activity of the solution at the end of the immobilization process $\left(\mathrm{U} / \mathrm{g}_{\text {support }}\right)$. A second analyzed immobilization parameter, the enzyme retention of activity, was determined as shown in Equation (2):

$$
R_{a}=\frac{A_{\text {hid }} \times 100}{U_{\text {theo }}} ; U_{\text {theo }}=U_{e}-U_{s}
$$

where $R_{a}$ is the enzyme retention of activity (\%) and $A_{h i d}$ is the hydrolytic activity of the biocatalyst (U/gbio).

\subsection{Esterification Activity of Biocatalysts}

The esterification activities of the biocatalysts were also evaluated. Esterification reactions were carried out in a jacketed reactor at $40{ }^{\circ} \mathrm{C}$ under mild stirring. Oleic acid $(10.1 \mathrm{~mL})$ and ethanol $(1.9 \mathrm{~mL})$ were used as substrates, using $0.2 \mathrm{~g}$ of biocatalyst in the reaction medium. Aliquots of $100 \mu \mathrm{L}$ were collected at different times for evaluation of the activities $(0,10 \mathrm{~min}, 20 \mathrm{~min}, 30 \mathrm{~min}, 40 \mathrm{~min}, 60 \mathrm{~min})$. Aliquots were added to a mixture of ethanol and acetone (1:1) (v/v) and the oleic acid content was determined by titration with $\mathrm{NaOH}(0.02 \mathrm{M})$, using an automatic titrator (G20 model, Mettler Toledo, 
Schwerzenbach, Switzerland). It is important to mention that experiments were analyzed in triplicates and that the experimental errors of esterification activities were calculated with confidence level of $95 \%$. It is important to note that one unit of enzymatic activity (1 IU or $1 \mathrm{U}$ ) corresponds to the amount of enzyme necessary to form $1 \mu \mathrm{mol}$ of ethyl oleate per minute under the described operating conditions. The expression $\mathrm{U} / \mathrm{g}_{\mathrm{bio}}$ corresponds to the enzymatic activity of $1 \mathrm{~g}$ of biocatalyst, after immobilization of the enzyme. The enzyme activity $\left(A_{\text {ester }}\right)$ was determined only in the linear region of the product concentration trajectory.

\subsection{Determination of Protein Concentration}

Protein concentrations in the supernatant during the immobilization process were evaluated in order to confirm the results obtained through the enzymatic activity analyses. Analyses were performed with help of the well-known Bradford method. Calibration was performed with bovine serum albumin (BSA) and light absorbance of the Bradford reagent at the wavelength of $595 \mathrm{~nm}$ [43], using a spectrophotometer (Power Wave XS model, BioTek, Winooski, VT, USA).

It is important to mention that some measurements were performed in triplicates and that the experimental errors of protein concentrations were calculated with confidence level of $95 \%$.

\subsection{Statistical Analysis}

Statistical analyses and empirical model building were performed with help of the Statistica Software, version 7.0, developed by Stat Soft Inc. (Tulsa, OK, USA). The modeling step was performed iteratively. Models were proposed and the correlation coefficients between the available experimental data and model calculations were computed. Models were discarded when correlation coefficients were smaller than 0.7 . When correlation coefficients were sufficiently close to 1 (for instance, above 0.8 ), the significance of model parameters was calculated. The main objective of the iterative procedure was the obtainment of models that could satisfactorily describe the available data with the smallest possible number of parameters.

\section{Conclusions}

Polystyrene core-shell particles were produced through combined suspension/emulsion polymerizations under different conditions, leading to production of polymer supports with distinct morphological properties (specific areas, volume of pores and average pore size). These supports were used for immobilization of lipase B from Candida antarctica (CAL-B), allowing for production of different biocatalysts. The performances of the biocatalysts were characterized in terms of hydrolytic and esterification activities. The obtained results indicated that modification of the reaction operation conditions can lead to significant changes of the morphological properties of the supports, leading to biocatalysts that present very different final performances. Particularly, the performances of some biocatalysts prepared at different conditions were better than the ones prepared with commercial supports, indicating that the combined suspension/emulsion polymerization technique can provide an interesting route for production of enzyme supports. It was observed that the specific area of the supports was the most influential morphological parameter in the analyzed system, although the 
increase of the specific area caused the decrease of the retention of activity, due to diffusional limitation effects. The specific area and volume of pores of the obtained supports were correlated to each other, as both variables depend on the accumulation of polymer material on the particle shell. The average pore diameter of the support did not affect the performances of the biocatalysts very significantly, probably because of the small diameter of CAL-B and the relatively large pore sizes of the supports.

\section{Acknowledgments}

The authors thank CNPq (Conselho Nacional de Desenvolvimento Científico e Tecnológico), CAPES (Coordenação de Aperfeiçoamento de Pessoal de Nível Superior) and FAPERJ (Fundação Carlos Chagas Filho de Apoio à Pesquisa do Estado do Rio de Janeiro) for scholarships and financial support. The authors also thank the Laboratório de Polímeros of Universidade Estadual do Rio de Janeiro (UERJ), the Laboratório de Catálise of Universidade Federal do Rio de Janeiro (Nucat/UFRJ) and the Laboratório de Engenharia de Materiais of Universidade Federal de São Carlos (UFSCar) for analytical support.

\section{Author Contributions}

Pinto, M.C.C. executed the experimental work under the guidance of Freire, D.M.G. and Pinto, J.C. Pinto, M.C.C., Freire, D.M.G. and Pinto, J.C. prepared the manuscript for publication.

\section{Conflicts of Interest}

The authors declare no conflict of interest.

\section{References}

1. Freire, D.M.G.; Castilho, L.R. Lipases em biocatálise. In Enzimas Em Biotecnologia: Produção, Aplicações E Mercado, 1st ed.; Bon, E.P.S., Ferrara, M.A., Corvo, M.L., Eds.; Editora Interciência: Rio de Janeiro, Brazil, 2008; Volume 1, pp. 369-380.

2. Cunha, A.G.; Besteti, M.D.; Manoel, E.A.; da Silva, A.A.T.; Almeida, R.V.; Simas, A.B.C.; Fernandez-Lafuente, R.; Pinto, J.C.; Freire, D.M.G. Preparation of core-shell polymer supports to immobilize lipase B from Candida Antarctica: Effect of the support nature on catalytic properties properties. J. Mol. Catal. B Enzym. 2014, 100, 59-67.

3. Forró, E.; Fülöp, F. Recent lipase-catalyzed hydrolytic approaches to pharmacologically important $\beta$ - and $\gamma$-amino acids. Curr. Med. Chem. 2012, 19, 6178-6187.

4. Gotor-Fernández, V.; Brieva, R.; Gotor, V. Lipases: Useful biocatalysts for the preparation of pharmaceuticals. J. Mol. Catal. B Enzym. 2006, 40, 111-120.

5. Fernandez-Lafuente, R.; Armisén, P.; Sabuquillo, P.; Fernández-Lorente, G.; Guisán, J.M. Immobilization of lipases by selective adsorption on hydrophobic supports. Chem. Phys. Lipids. 1998, 93, 185-197.

6. Villeneuve, P.; Muderhwa, J.M.; Graille, J.; Haas, M.J. Customizing lipases for biocatalysis: A survey of chemical, physical and molecular biological approaches. J. Mol. Catal. B Enzym. 2000, 9, 113-148. 
7. Cammarota, M.C.; Freire, D.M.G. A review on hydrolytic enzymes in the treatment of wastewater with high oil and grease content. Bioresour. Technol. 2006, 97, 2195-2210.

8. Rigo, E.; Rigoni, R.E.; Lodea, P.; Oliveira, D.; Freire, D.M.G.; di Luccio, M. Application of different lipases as pretreatment in anaerobic treatment of wastewater. Environ. Eng. Sci. 2008, $25,1243-1248$.

9. Ribeiro, B.D.; Castro, A.M.; Coelho, M.A.Z.; Freire, D.M.G. Production and use of lipases in bioenergy: A review from the feedstocks to biodiesel production. Enzym. Res. 2011, 2011, 1-16.

10. Ranganathan, S.V.; Narasimhan, S.L.; Muthukumar, K. An overview of enzymatic production of biodiesel. Bioresour. Technol. 2008, 99, 3975-3981.

11. Tan, T.; Lu, J.; Nie, K.; Deng, L.; Wang, F. Biodiesel production with immobilized lipase: A review. Biotechnol. Adv. 2010, 28, 628-634.

12. Castro, H.F.; Zanin, G.M.; Moraes, F.F.; Sá-Pereira, P. Imobilização de enzimas e sua estabilização. In Enzimas Em Biotecnologia: Produção, Aplicações E Mercado, 1st ed.; Bon, E.P.S., Ferrara, M.A., Corvo, M.L., Eds.; Editora Interciência: Rio de Janeiro, Brazil, 2008; Volume 1, pp. 123-151.

13. Tischer, W.; Kasche, V. Immobilized enzymes: Crystals or carriers?. Trends Biotechnol. 1999, 17, 326-335.

14. DiCosimo, R.; McAuliffe, J.; Poulose, A.J.; Bohlmann, G. Industrial use of immobilized enzymes. Chem. Soc. Rev. 2013, 42, 6437-6474.

15. Liese, A.; Hilterhaus, L. Evaluation of immobilized enzymes for industrial applications. Chem. Soc. Rev. 2013, 42, 6236-6249.

16. Stepankova, V.; Bidmanova, S.; Koudelakova, T.; Prokop, Z.; Chaloupkova, R.; Damborsky, J. Strategies for stabilization of enzymes in organic solvents. ACS Catal. 2013, 3, 2823-2836.

17. Rodrigues, R.C.; Ortiz, C.; Berenguer-Murcia, A.; Torres, R.; Fernández-Lafuente, R. Modifying enzyme activity and selectivity by immobilization. Chem. Soc. Rev. 2013, 42, 6290-6307.

18. Verma, M.L.; Barrow, C.J.; Puri, M. Nanobiotechnology as a novel paradigm for enzyme immobilisation and stabilisation with potential applications in biodiesel production. Appl. Microbiol. Biotechnol. 2013, 97, 23-39.

19. Hwang, E.T.; Gu, M.B. Enzyme stabilization by nano/microsized hybrid materials. Eng. Life Sci. 2013, 13, 49-61.

20. Garcia-Galan, C.; Berenguer-Murcia, A.; Fernandez-Lafuente, R.; Rodrigues, R.C. Potential of different enzyme immobilization strategies to improve enzyme performance. Adv. Synth. Catal. 2011, 353, 2885-2904.

21. Cowan, D.A.; Fernandez-Lafuente, R. Enhancing the functional properties of thermophilic enzymes by chemical modification and immobilization. Enzyme Microb. Technol. 2011, 49, 326-346.

22. Emond, S.; Montanier, C.; Nicaud, J.M.; Marty, A.; Monsan, P.; André, I.; Remaud-Siméon, M. New efficient recombinant expression system to engineer Candida antarctica lipase B. Appl. Environ. Microbiol. 2010, 76, 2684-2687.

23. Barbosa, O.; Ruiz, M.; Ortiz, C.; Fernández, M.; Torres, R.; Fernandez-Lafuente, R. Modulation of the properties of immobilized CALB by chemical modification with 2,3,4-trinitrobenzenesulfonate or ethylendiamine: Advantages of using adsorbed lipases on hydrophobic supports. Process Biochem. 2012, 47, 867-876. 
24. Uppenberg, J.; Öhmer, N.; Norin, M.; Hult, K.; Kleywegt, G.J.; Patkar, S.; Waagen, V.; Anthomen, T.; Jones, T.A. Crystallographic and molecular-modeling studies of lipase $b$ from candida antarctica reveal a stereospecificity pocket for secondary alcohols. Biochemistry 1995, 34, $16838-16851$.

25. Palomo, J.M.; Muñoz, G.; Fernández-Lorente, G.; Mateo, C.; Fernández-Lafuente, R.; Guisán, J.M. Interfacial adsorption of lipases on very hydrophobic support (octadecylSepabeads): Immobilization, hyperactivation and stabilization of the open form of lipases. J. Mol. Catal. B Enzym. 2002, 19-20, 279-286.

26. Kennedy, J.T.; White, C.A. Principles of immobilization of enzymes. In Handbook of Enzyme Biotechnology, 2nd ed.; Wiseman, A., Ed.; John Wiley \& Sons: New York, NY, USA, 1985; pp. 147-157.

27. Kahraman, M.V.; Bayramoğlu, G.; Kayaman-Apohan, N.; Güngör, A. $\alpha$-Amylase immobilization on functionalized glass beads by covalent attachment. Food Chem. 2007, 104, 1385-1392.

28. Pinto, J.C.; Alves, T.L.M.; Lima, E.L.; Salim, V.M.M.; Figueiredo, K.C.S.; Lenzi, M.K. Processo de Preparação de Resina Polimérica com Distribuição Bimodal de Pesos Moleculares e/ou com Estrutura Casca-Núcleo e seu uso. PI 0400803-0, 30 March 2004.

29. Besteti, M.D. Produção de Partículas Poliméricas Com Porosidade Controlada Para A Preparação de Biocatalisadores. Ph.D Thesis, Universidade Federal do Rio de Janeiro, Rio de Janeiro, Brazil, 2011.

30. Figueiredo, K.C.S.; Salim, V.M.M.; Alves, T.L.M.; Pinto, J.C. Lysozyme Adsorption onto Different Supports: A Comparative Study. Adsorption 2005, 11, 131-138.

31. Besteti, M.D.; Cunha, A.G.; Freire, D.M.G.; Pinto, J.C. Core/Shell polymer particles by semibatch combined suspension/emulsion polymerizations for enzyme immobilization. Macromol. Mater. Eng. 2014, 299, 135-143.

32. Manoel, E.A.; Pais, K.C.; Flores, M.C.; Miranda, L.S.M.; Coelho, M.A.Z.; Simas, A.B.C.; Freire, D.M.G.; de Souza, R.O.M.A. Kinetic resolution of a precursor for myo-inositol phosphates under continuous flow conditions. J. Mol. Catal. B Enzym. 2013, 87, 139-143.

33. Manoel, E.A.; Pais, K.C.; Cunha, A.G.; Coelho, M.A.Z.; Freire, D.M.G.; Simas, A.B.C. On the kinetic resolution of sterically hindered myo-inositol derivatives in organic media by lipases. Tetrahedron Asymmetry 2012, 23, 47-52.

34. Manoel, E.A.; Pais, K.C.; Cunha, A.G.; Simas, A.B.C.; Coelho, M.A.Z.; Freire, D.M.G. Kinetic resolution of 1,3,6-tri-O-benzyl-myo-inositol by Novozym 435: Optimization and enzyme reuse. Org. Process Res. Dev. 2012, 16, 1378-1384.

35. Cunha, A.G.; da Silva, A.A.T.; da Silva, A.J.R.; Tinoco, L.W.; Almeida, R.V.; de Alencastro, R.B.; Simas, A.B.C.; Freire, D.M.G. Efficient kinetic resolution of $( \pm$ )-1,2-O-benzyl-myo-inositol with the lipase B of Candida antarctica. Tetrahedron Asymmetry 2010, 21, 2899-2903.

36. Simas, A.B.C.; da Silva, A.A.T.; Cunha, A.G.; Assumpção, R.S.L.; Hoelz, V.B.; Neves, B.C.; Galvão, T.C.; Almeida, R.V.; Albuquerque, M.G.; Freire, D.M.G.; et al. Kinetic resolution of $( \pm)$-1,2-O-isopropylidene-3,6-di-O-benzyl-myo-inositol by lipases: An experimental and theoretical study on the reaction of a key precursor of chiral inositols. J. Mol. Catal. B Enzym. 2011,70, 32-40. 
37. Mojovic, L.; Knezevic, Z.; Popadic, R.; Jovanovic, S. Immobilization of lipase from Candida rugosa on a polymer support. Appl. Microbiol. Biotechnol. 1998, 50, 676-681.

38. Bayne, L.; Ulijn, R.V.; Halling, P.J. Effect of pore size on the performance of immobilized enzymes. Chem. Soc. Rev. 2013, 42, 9000-9010.

39. Lenzi, M.K.; Silva, F.M.; Lima, E.L.; Pinto, J.C. Semibatch styrene suspension polymerization processes. J. Appl. Polym. Sci. 2003, 89, 3021-3038.

40. Cunha, A.G. Resolução Cinética de Derivados de Mio-inositol Catalisada Por Lipases. Ph.D Thesis, Universidade Federal do Rio de Janeiro, Rio de Janeiro, Brazil, 2011.

41. Cunha, A.G.; Fernández-Lorente, G.; Bevilaqua, J.V.; Destain, J.; Paiva, L.M.C.; Freire, D.M.G.; Fernández-Lafuente, R.; Guisán, J.M. Immobilization of Yarrowia lipolytica Lipase: A comparison of stability of physical adsorption and covalent attachment techniques. Appl. Biochem. Biotechnol. 2008, 146, 49-56.

42. Cunha, A.G.; Fernández-Lorente, G.; Gutarra, M.L.E.; Bevilaqua, J.V.; Almeida, R.V.; Paiva, L.M.C.; Fernández-Lafuente, R.; Guisán, J.M.; Freire, D.M.G. Separation and immobilization of lipase from Penicillium simplicissimum by selective adsorption on hydrophobic supports. Appl. Biochem. Biotechnol. 2009, 156, 563-575.

43. Bradford, M.M. A rapid and sensitive method for the quantitation of microgram quantities of protein utilizing the principle of protein-dye binding. Anal. Biochem. 1976, 72, 248-254.

Sample Availability: Samples are not available, but can be produced for those who may be interested in the supports and biocatalysts.

(C) 2014 by the authors; licensee MDPI, Basel, Switzerland. This article is an open access article distributed under the terms and conditions of the Creative Commons Attribution license (http://creativecommons.org/licenses/by/3.0/). 